\title{
PENINGKATAN KEDISIPLINAN GURU DALAM KEHADIRAN MENGAJAR DI KELAS MELALUI SUPERVISI KEPALA SEKOLAH PADA SMA NEGERI 2 BANGKO KABUPATEN ROKAN HILIR
}

\author{
(Improvement of Teacher's Discipline in Teaching Attendance through School Head \\ Supervision at SMA Negeri 2 Bangko Kabupaten Rokan Hilir)
}

\author{
Oleh: Hayati Tatoe*) \\ E-mail : hayatitatoe@gmail.com
}

${ }^{*}$ Kepala Sekolah SMAN 2 Bangko

\begin{abstract}
The purpose of this study was to determine the increase discipline in the presence of teachers teaching in the classroom through waskat Principal at SMA Negeri 2 Bangko Rokan Hilir. This study uses action research design school (PTS) designed two cycles of the first cycle and the second cycle. The subjects were teachers of SMA Negeri 2 Bangko. Analysis of data used in this research was qualitative data analysis derived from primary data and empirical. Based on the findings, it was concluded that supervisi Principal, Discipline Teachers can increase in the presence of teaching in the classroom, it is seen 97,98\% \% of respondents stated that supervisition Principal very role in improving teacher discipline, especially in the presence of classroom teaching.
\end{abstract}

Key words: Teachers' Discipline, teaching presence, supervision, principal

\section{PENDAHULUAN}

Guru adalah pendidik profesional yang mempunyai tugas, fungsi, dan peran penting dalam mencerdaskan kehidupan bangsa. Guru yang profesional diharapkan mampu berpartisipasi dalam pembangunan nasional untuk mewujudkan insan Indonesia yang bertakwa kepada Tuhan YME, unggul dalam ilmu pengetahuan dan teknologi, memiliki jiwa estetis, etis, berbudi pekerti luhur, dan berkepribadian.

Keteladanan guru dapat dilihat dari prilaku guru sehari-hari baik di dalam sekolah maupun di luar sekolah. Selain keteladanan guru, kedisiplinan guru juga menjadi salah satu hal penting yang harus dimiliki oleh guru sebagai seorang pengajar dan pendidik. Fakta dilapangan yang sering kita jumpai disekolah adalah kurang disiplinnya guru, terutama masalah disiplin guru masuk ke dalam kelas pada saat kegiatan pembelajaran di kelas.
SMA Negeri 2 Bangko adalah salah satu SMA Negeri yang berada di wilayah Kecamatan Bangko, Kabupaten Rokan Hilir. SMA ini memiliki 53 orang guru untuk mendidik dan mengajar 644 orang siswa. Disiplin guru datang tepat waktu disaat jam mengajar dapat dikategorikan rendah di sekolah ini. Hal ini dapat diketahui antara lain dalam menjalankan tugas masih tergantung pada pengawasan kepala sekolah, dalam memasuki kelas untuk mengajar masih ada yang terlambat, pada saat guru tidak dapat mengajar guru hanya dapat memberikan catatan kepada anak didik, administrasi kelas yang kurang lengkap, tidak membuat rencana pelaksanaan pembelajaran, tidak mengisi buku nilai dan banyak sekali jenis ketidak disiplinan guru.

Kedisiplinan guru diartikan sebagai sikap mental yang mengandung kerelaan mematuhi semua ketentuan, peraturan dan norma yang berlaku dalam menunaikan 
tugas dan tangung jawab. Dari pengertian tersebut disimpulkan; kedisiplinan guru adalah sikap penuh kerelaan dalam mematuhi semua aturan dan norma yang ada dalam menjalankan tugasnya sebagai bentuk tanggung jawabnya.

Peningkatan disiplin guru dalam kehadiran mengajar di kelas sangat perlu diperhatikan. Menurut Hasibuan (2005), waskat (pengawasan melekat) adalah tindakan nyata paling efektif dalam mewujudkan kedisiplinan guru di sekolah. Dengan waskat berarti atasan harus aktif dan langsung mengatasi perilaku, moral, sikap, gairah kerja dan prestasi kerja bawahannya.

Kepala sekolah sebagai supervisor harus mampu membantu guru meningkatkan kapasitasnya untuk membelajarkan peserta didik secara optimal. Dengan demikian maka, kepala sekolah diharapkan dengan sendirinya dapat meningkatkan disiplin guru dalam kehadiran mengajar di kelas sehingga proses belajar mengajar berjalan sesuai dengan jadwal yang telah ditetapkan. Berdasarkan dari latar belakang di atas, penulis tertarik untuk meneliti masalah tersebut dengan judul "Supervisi Kepala Sekolah Untuk Meningkatkan Disiplin Guru Dalam Kehadiran Mengajar Di

\section{Kelas Pada SMANegeri 2 Bangko Kabupaten Rokan Hilir".}

\section{METODE PENELITIAN}

Subjek penelitian tindakan sekolah ini adalah guru di SMA Negeri 2 Bangko Kabupaten Rokan Hilir sebanyak 53 orang. Penelitian ini dilakukan pada SMA Negeri 2 Bangko Kabupaten Rokan Hilir. Waktu Penelitian Agustus - November 2019. Metode yang digunakan dalam penelitian ini adalah metode Penelitian Tindakan Sekolah (PTS). Sementara pendekatan penelitian yang digunakan adalah pendekatan kuntitatif. Permasalahan ini ditindaklanjuti dengan cara menerapkan supervisi kepala sekolah yang dilakukan oleh kepala sekolah, kegiatan tersebut diamati kemudian dianalisis dan direfleksi. Hasil refleksi kemudian diterapkan kembali pada siklus-siklus berikutnya.

Peneliti menggunakan model ini karena dianggap paling praktis dan aktual. Kegiatan penelitian tindakan sekolah ini, terdiri atas beberapa tahap, yaitu: Perencanaan, Pelaksanaan, Pengamatan, dan Refleksi. Langkah-langkah penelitian tindakan sekolah ini dapat dilihat Gambar $1 .:$

\section{Alur Siklus PTK}

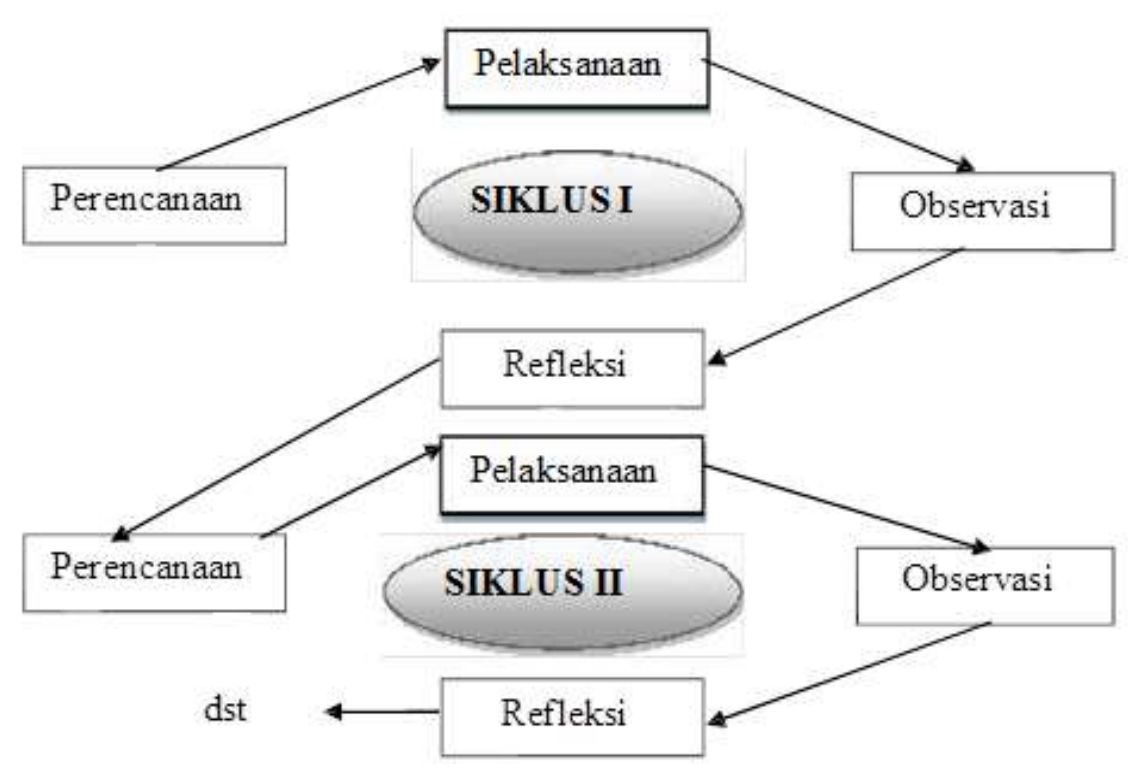


Tindakan yang dilakukan dalam penelitian ini adalah pengawasan (supervisi) mengenai kedisiplinan guru dalamkehadiran di kelas dalam proses pembelajaran oleh kepala sekolah. Diharapkan dengan adanya supervisi yang diberikan oleh kepala sekolah akan terjadi perubahan atau peningkatan kedisiplinan guru dalam kehadiran di kelas dalam proses pembelajaran.

Instrumen penelitian yang digunakan dalam penelitian tindakan sekolah ini adalah: Skala Penilaian, Lembar Observasi/Pengamatan dan angket. Analisis data yang digunakan dalam penelitian ini adalah analisa data kualitatif yang bersumber dari data primer maupun empiris. Melalui analisis data ini, dapat diketahui ada tidaknya peningkatan kedisiplinan guru dalam kehadiran di kelas yang merupakan fokus dari penelitian tindakan sekolah ini.

Pada siklus 1 penulis membuat perencanaan. Perencanaan adalah langkah awal yang dilakukan oleh penulis saat akan memulai tindakan. Agar perencanaan mudah dipahami dan dilaksanakan oleh penulis yang akan melakukan tindakan, maka penulis membuat rencana tindakan sebagai berikut:

a. Merumusan masalah yang akan dicari solusinya. Dalam penelitian ini masalah yang akan dicari solusinya adalah masih banyaknya guru yang kurang disiplin dalam kehadiran di kelas pada proses belajar mengajar,

b. Merumusan tujuan penyelesaian masalah/tujuan menghadapi tantangan/tujuan melakukan inovasi/tindakan. Dalam penelitian ini penulis mengambil rencana untuk melakukan tindakan melalui keteladanan kepala sekolah untuk meningkatkan kedisiplinan guru dalam kehadiran mengajar di kelas pada proses belajar mengajar,

c. Merumuskan indikator keberhasilan penerapan superisi oleh Kepala Sekolah dalam meningkatkan disiplin guru dalam kehadiran mengajar di kelas pada proses belajar mengajar. Indikator keberhasilan penerapan tindakan ini penulis tetapkan sebesar $75 \%$, artinya tindakan inidinyatakan berhasil bila $75 \%$ guru tidakterlambat masuk mengajar di kelas dalam proses pembelajaran,

d. Merumuskan langkah-langkah kegiatan penyelesaian masalah/kegiatan menghadapi tantangan/kegiatan melakukan tindakan.Langkah-langkah yang diambil penulis dalam melakukan tindakan antara lain adalah melakukan sosialisasi kepada para guru mengenai penelitian yang akan dilaksanakan, serta menyampaikan tujuan dari penerapan tindakan yang dilakukan oleh penulis. Kepada para guru disampaikan mengenai supervisi Kepala Sekolah ke kelas yang akan diterapkan dalam penelitian ini.Pada siklus pertama ini, akan dipampang /ditempel diruang guru, maupun diruang TU, peringkat nama-nama guru yang paling rendah tingkat keterlambatan masuk kelasnya sampai yang paling tinggi tingkat keterlambatannya,

e. Mengidentifikasi warga sekolah dan atau pihak-pihak terkait lainnya yang terlibat dalam penyelesaian masalah/menghadapi tantangan/melakukan tindakan. Penulis melakukan identifikasi siapa saja yang dilibatkan dalam penelitian ini. Pihakpihak yang dilibatkan dalam penelitian ini adalah: guru, guru piket, TU, dan siswa, 
f. Mengidentifikasi metode pengumpulan data yang akan digunakan. Metode pengumpulan data yang diambil oleh penulis merupakan data kualitatif melalui observasi, pengamatan serta wawancara kepada siswa mengenai kehadiran guru di kelas pada kegiatan belajar mengajar,

g. Penyusunan instrumen pengamatan dan evaluasi. Dalam pengambilan data, penulis menggunakan instrument berupa lembar observasi/pengamatan, skala penilaian serta angket yang disebarkan kepada guru dan siswa, untuk mengetahui penilaian mengenai tingkat kehadiran guru di kelas dan keteladanan Kepala Sekolah dalam proses kegiatan belajar mengajar

h. Mengidenifikasi fasilitas yang diperlukan. Fasilitas atau alat bantu yang digunakan penelitian ini antara lain:

- kertas (lembar pengamatan),

- alat tulis berupa balpoin,

- jam dinding yang ada disetiap kelas, dan

- rekap jumlah kehadiran dari setiap guru.

Sesuai dengan rencana, tiga kali pertemuan berturut-turut kepala sekolah hadir 30 menit sebelum jam pelajaran pertama dimulai dan masuk di kelas tepat jam pertama dimulai yaitu pukul 07.30 WIB dengan membawa perangkat pembelajaran yang lengkap dan meninggalkan kelas tepat pada saat pergantian jam pelajaran berikutnya.

Pelaksanaan penelitian tindakan sekolah selanjutnya dilaksanakan melalui beberapa kegiatan, antara lain:

a. Menyebarkan lembar pengamatan kepada setiap Ketua Kelas atau Sekretaris kelas sebanyak 644 eks., sesuai dengan banyaknya jumlah rombongan belajar di SMA Negeri 2 Bangkoterdiri dri kelas X, XI IPA, XI IPS, XII IPA dan XII IPS. Dalam lembar pengamatan itu, telahdibuat daftar guru yangmengajar di kelas itu setiap jam dan diberi kolom jam masuk kelas serta jam keluar kelas. Lembar pengamatan dapat dilihat pada lampiran

b. Berkoordinasi dengan petugas piketyang setiap hari terdiri dari 2 orang petugas, yaitu dari guru yang tidak mempunyai jam mengajar pada hari itu dan satu orang dari tata usaha. Petugas piket akan mengedarkan daftar hadir guru di kelas yang telah dibuat agar dapat melihat tingkat kehadiran guru disetiap kelas dan disetiap pergantian jam pelajaran. Guru yang terlambat lebih dari 15 menit, dianggap tidak hadir dan diberi tanda silang,

c. Setelah selesai jam pelajaran, dilakukan rekapitulasi dari hasil pengamatan, baik dari guru piket, dari siswa maupun dari penulis,

d. Kegiatan tersebut dilakukan terus setiap hari kepada setiap guru selama tujuh minggu (dua siklus).

Pengamatan atau observasi dilakukan oleh peneliti dengan menggunakan lembar observasi selama satu minggu (satu siklus), untuk semua guru yang berjumlah 53 orang. Selama pengamatan peneliti dibantu atau berkolaborasi dengan guru piket. Pengamatan oleh peneliti meliputi:

a. Kehadiran guru di kelas,

b. Tingkat keterlambatan guru masuk kelas,

c. Waktu meninggalkan kelas setelah selesai pelajaran.

Dari hasil pengamatan serta rekap dari tingkat kehadiran guru di kelas pada proses belajarmengajar dapat dilihat pada Tabel 1 dibawah. 
HASIL DAN PEMBAHASAN

Berdasarkan uji validitas menggunakan instrumen lembar penilaian validitas diperoleh hasil pada tabel 2 sebagai berikut:

\section{Tabel 1}

Rekapitulasi Tingkat Keterlambatan Guru pada Kehadiran di Kelas Pada Siklus I

\begin{tabular}{|c|c|c|c|}
\hline & \multicolumn{3}{|c|}{ Waktu Keterlambatan } \\
\hline & $\begin{array}{c}\text { Kurang dari } \\
10 \text { menit }\end{array}$ & $\begin{array}{c}10 \text { menit sampai } \\
15 \text { menit }\end{array}$ & $\begin{array}{l}\text { Lebih dari } \\
15 \text { menit }\end{array}$ \\
\hline Jumlah & 14 & 21 & 9 \\
\hline Persentase $(\%)$ & $26,42 \%$ & $39,62 \%$ & $16,98 \%$ \\
\hline
\end{tabular}

Dari hasil rekapitulasi tingkat keterlambatan guru di kelas pada proses pembelajaran diperoleh data, sebanyak14 orang guru terlambat masuk kelas kurang dari 10 menit, 21 orangguru terlambat masuk kelas 10 menit sampai dengan 15 menit, dan 9 orang guru terlambat masuk kelas lebih dari 15 menit, serta 9 orang guru yang hadir tepat waktu mengajar di kelas. Untuk lebih jelasnya dapat digambarkan pada Gambar 2.

Gambar 2

Tingkat Keterlambatan Guru Masuk Kelas pada Proses Belajar Mengajar pada Siklus Pertama

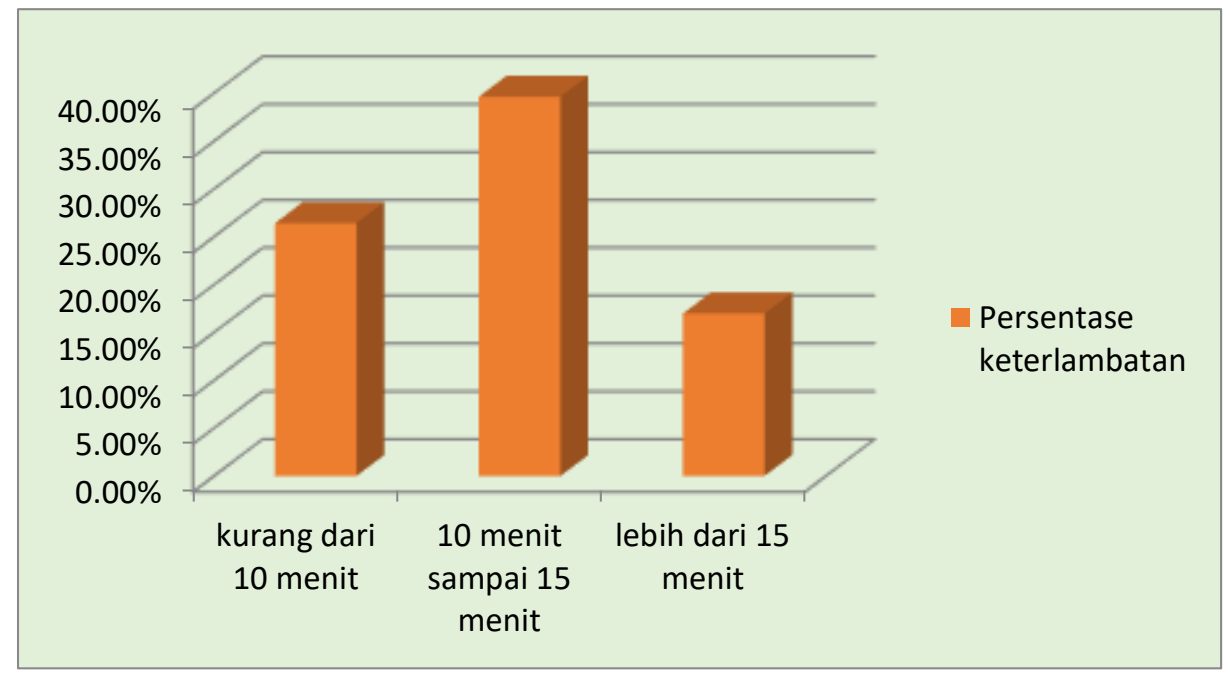

Gambar 2 menjelaskan tingkat keterlambatan guru di kelas pada proses pembelajaran diperoleh data, sebanyak $26,42 \%$ terlambat masuk kelas kurang dari $39,62 \%$ terlambat masuk kelas 10 menit sampai dengan 15 menit, dan 6,98\% terlambat masuk kelas lebih dari 15 menit. Guru yang hadir tepat waktu mengajar di kelas hanya $16,98 \%$.
Dari data tersebut dapat ditarik kesimpulan bahwa tingkat keterlambatan guru masuk kelas lebih dari 15 menit pada proses kegiatan belajar mengajar masih tinggi yaitu 9 orang atau $16,98 \%$. Berdasarkan indikator yang telah ditetapkan bahwa keberhasilan tindakan ini adalah $75 \%$, atau bila $75 \%$ guru tidak terlambat lebih dari 10 menit. Pada siklus pertama ini guru yang tidak terlambat lebih dari 10 menit baru 20\%, jadi peneliti 
berkesimpulan harus diadakan penelitian atau tindakan lagi pada siklus berikutnya atau siklus kedua. Setelah selesai satu siklus maka diadakan refleksi mengenai kelemahan/ kekurangan pelaksanaan tindakan pada siklus 1 .

Refleksi dilaksanakan bersama kolaborator untuk menentukan tindakan perbaikan pada siklus berikutnya. Dari hasil refleksi pada siklus pertama, peneliti merencanakan untuk melakukan tindakan sama pada siklus kedua. Peneliti merencanakan untuk mengumumkan hasil observasi mengenai tingkat keterlambatan guru masuk kelas dalam proses belajar mengajar, pada kegiatan upacara bendera hari Senin. Hal ini, terlebih dahulu disosialisasikan kepada semua guru pada saat refleksi siklus pertama.

Didasarkan pada hasil observasi, hasil pengamatan dan hasil wawancara pada siklus I, tindakan pada siklus II tidak berbeda, hanya beberapa peningkatan kualitas tindakan seperti berikut ini:

a. setiap hari kepala sekolah hadir 30 menit sebelum jam pertama dimulai dan meninggalkan sekolah setelah jam pelajaran terakhir selesai,

b. selalu membawa perangkat pembelajaran yang lengkap setiap masuk mengajar di kelas,

c. setiap hari mengecek kehadiran guru mengajar di kelas melalui jurnal kelas, d. mengisi buku agenda guru,

e. melaksanakan Supervisi.

Pengamatan/observasi dilakukan dengan menggunakan lembar observasi selama tujuh minggu (dua siklus), untuk semua guru yang berjumlah 15 orang. Selama pengamatan peneliti dibantu atau berkolaborasi dengan guru piket. Pengamatan meliputi:

a. kehadiran guru di kelas

b. tingkat keterlambatan guru masuk kelas

c. waktu meninggalkan kelas setelah selesai pelajaran.

Peneliti juga melakukan penilaian dari hasil lembar observasi yang dibagikan kepada semua siswa untuk mengamati kehadiran guru di kelas. Dari hasil rekapitulasi tingkat keterlambatan guru di kelas pada proses pembelajaran diperoleh data, sebanyak 47 orang hadir tepat waktu mengajar di kelas atau 88,68\%, 6 orang guru terlambat masuk kelas kurang dari 10 menit atau sebanyak $11,32 \%$, tidak ada lagi guru yang terlambat baik 10 menit sampai 15 menit maupun lebih dari 15 menit. Untuk lebih jelasnya, tingkat keterlambatan guru masuk kelas pada proses belajar mengajar pada siklus kedua digambarkan pada Tabel 2 dan Gambar 3.:

Tabel 2

Rekapitulasi Tingkat Keterlambatan Guru pada Kehadiran di Kelas Pada Siklus II

\begin{tabular}{|c|c|c|c|}
\hline & \multicolumn{3}{|c|}{ Waktu Keterlambatan } \\
\hline & $\begin{array}{c}\text { Kurang dari } \\
10 \text { menit }\end{array}$ & $\begin{array}{c}10 \text { menit sampai } \\
15 \text { menit }\end{array}$ & $\begin{array}{l}\text { Lebih dari } \\
15 \text { menit }\end{array}$ \\
\hline Jumlah & 6 & 0 & 0 \\
\hline Persentase $(\%)$ & $11,32 \%$ & $0 \%$ & $0 \%$ \\
\hline
\end{tabular}




\section{Gambar 3}

Tingkat Keterlambatan Guru Masuk Kelas pada Proses Belajar Mengajar pada Siklus Kedua

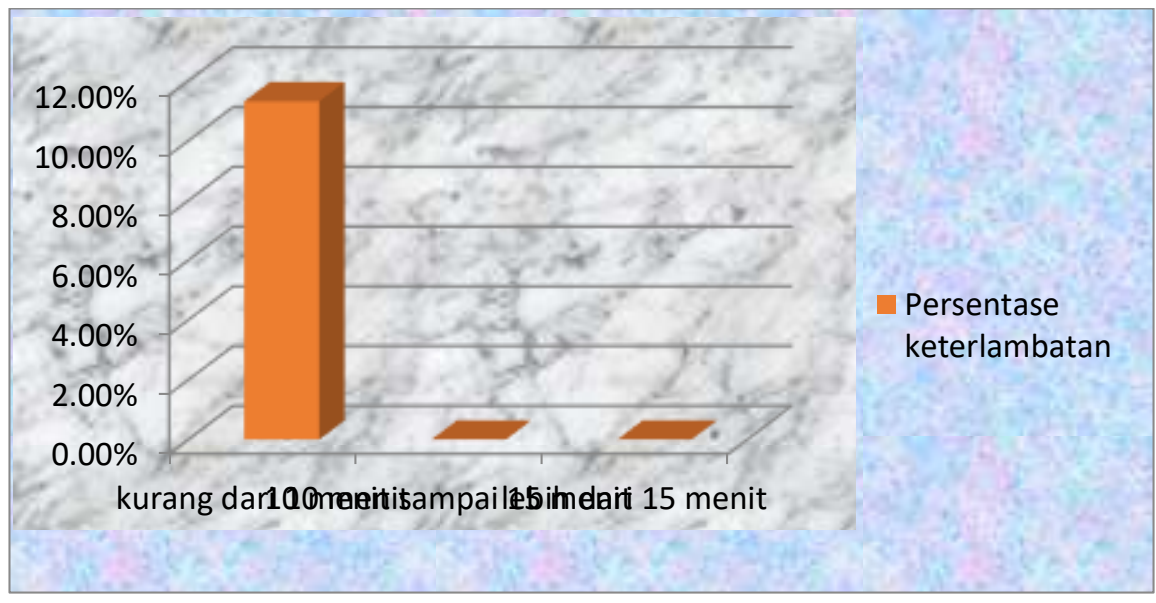

Dari hasil observasi pada siklus pertama dan siklus kedua dapat dilihat ada penurunan tingkat keterlambatan guru di kelas pada kegiatan belajar mengajar, atau terdapat peningkatan kehadiran guru di kelas. Setelah selesai pelaksanaan tindakan pada siklus kedua maka diadakan refleksi mengenai kelemahan atau kekurangan dari pelaksanaan tindakan pada siklus kedua tersebut.

Dari hasil observasi dan data yang diperoleh, peneliti mengambil kesimpulan bahwa tindakan yang dilaksanakan pada siklus kedua dinyatakan berhasil, karena terdapat $11,32 \%$ guru yang terlambat kurang dari 10 menit, dan tidak ada lagi guru yang terlambat baik 10 menit sampai 15 menit maupun lebih dari 15 menitatau melebihi target yang telah ditentukan sebesar $75 \%$.

Pada tahap ini tidak ada lagi guru yang terlambat masuk mengajar di kelas lebih dari 15 menit. Guru yang biasanya terlambat masuk mengajar di kelas terutama pada jam pelajaran pertama karena faktor transportasi menemukan solusinya, yaitu ikut pada teman sesama guru atau pegawai yang menggunakan transportasi (kendaraan) pribadi.

Tabel 3.

Tanggapan Responden tentang Upaya Meningkatkan Disiplin Guru dalam Kehadiran Mengajar di Kelas melalui Supervisi Kepala Sekolah

\begin{tabular}{|l|c|c|c|c|c|c|c|}
\hline \multirow{2}{*}{ Kriteria } & \multirow{2}{*}{ Bobot } & \multirow{2}{*}{ F } & \multirow{2}{*}{ Nilai } & \multirow{2}{*}{$\%$} & \multicolumn{2}{|c|}{ Rata-rata } & Tingkat \\
\cline { 5 - 7 } & & & & & Skor & $\mathbf{\%}$ & Partisipasi \\
\hline Selalu & 4 & 34 & 136 & $71,58 \%$ & & & \\
Hampir Selalu & 3 & 17 & 51 & $26,40 \%$ & & & \\
Jarang & 2 & 1 & 2 & $1,05 \%$ & & & \\
Tidak Pernah & 1 & 1 & 1 & $0,53 \%$ & & & \\
\hline \multicolumn{1}{|c|}{ Jumlah } & & $\mathbf{5 3}$ & $\mathbf{1 9 0}$ & $\mathbf{1 0 0}$ & $\mathbf{3 , 7 6}$ & & Sangat Tinggi \\
\hline
\end{tabular}


Dari Tabel 3 diperoleh gambaran bahwa waskat Kepala Sekolah dapat meningkatkan disiplin guru dalam kehadiran mengajar di kelas, terutama pada jam pelajaran pertama, hal ini ditandai dengan skor 3,76. Berdasarkan penelitian terhadap responden ternyata terdapat $97,98 \%$ dari jumlah responden menyatakan bahwa supervisi Kepala Sekolah sangat berperanan dalam meningkatkan disiplin Guru terutama dalam kehadiran mengajar di kelas. Sedangkan yang 2,02\% karena faktor transportasi, yaitu guru yang masih menggunakan transportasi umum, dimana akses jalan masuk ke sekolah memang agak sulit. Karena bagaimana pun seorang guru atau tenaga kependidikan (pegawai), merupakan cermin bagi anak didiknya dalam sikap atau teladan, dan sikap disiplin guru dan tenaga kependidikan (pegawai) akan memberikan warna terhadap hasil pendidikan yang jauh lebih baik.

Guru dalam melaksanakan tugastugasnya di sekolah perlu dinilai, dibina, dan dibimbing. Oleh karena itu waskat (pengawasan yang melekat) sangat diperlukan dalam meningkatkan disiplin guru terutama dalam kehadirannya mengajar di dalam kelas.

\section{KESIMPULAN DAN SARAN}

Berdasarkan hasil penelitian, disimpulkan bahwa supervisi Kepala Sekolah dapat meningkatkan Kedisiplinan Guru dalam kehadiran mengajar di kelas, hal ini terlihat 97,98\% 97,98\% dari jumlah responden menyatakan bahwa Kepala
Sekolah sangat berperanan dalam meningkatkan disiplin Guru terutama dalam kehadiran mengajar di kelas.

Berdasarkan hasil dan pembahasan maka disarankan:

1. Kepala Sekolah sebagai pemimpin di suatu Lembaga Pendidikan perlu mengadakan pengawasan yang supervisi pada seluruh warga sekolah yang dipimpinnya.

2. Setiap tenaga kependidikan seperti guru memiliki karakteristik khusus, yang berbeda satu sama lain sehingga memerlukan perhatian dan pelayanan khusus dari pimpinannya yaitu kepala sekolah.

\section{DAFTAR PUSTAKA}

Arikunto, Suharsimi. (2006). Dasar-dasar Supervisi. Rineka Cipta. Jakarta

Asmiarsih. (2012). Sumber Daya Manusia. Alfabeta. Bandung

Hasibuan, M. (2006). Manajemen Sumber Daya Manusia. Bumi Aksara. Jakarta

Rawung. (2013). The Effect of Leadership on the Work Motivation of Higher Education Administration Employees (Study at Manado State University). IOSR Journal of Business and Management (IOSR-JBM).

Sagala, Syaiful. (2011). Kemampuan Profesional Guru dan Tenaga Kependidikan. Alfabeta. Bandung

Sukendar dan Usman, H. (2013). Karakteristik Kepemimpinan Efektif Kepala Sekolah SMP Negeri 1 Banguntapan. Jurnal Akuntabilitas Manajemen Pendidikan. 1(2): 285-29. 